\title{
XXX Congresso Brasileiro de Cefaleia, o dilema da medicina baseada em evidência e o SUS
}

Chegamos ao final de mais uma edição do nosso congresso e acredito que o balanço é altamente positivo, já deixando saudades e crescente expectativa para o próximo evento.

Sem sombra de dúvidas, o instante de discussão de casos por renomados especialistas é um momento único e sempre muito esperado por todos. Entretanto, como em outros congressos, é natural que aconteçam embates de ideias e condutas díspares entre os colegas que analisam a problemática virtual de casos brilhantemente selecionados. De uma forma geral, acabamos por entender as nuances de cada conduta, mesmo não concordando com essa ou aquela escolha, e ao final é cumprida a tarefa de ampliar ainda mais nosso leque de conhecimentos e alternativas diante de casos complexos, ou apenas pitorescos.

Ora, mas por que condutas tão distintas em casos pontuais se vivemos a "Era da Medicina Baseada em Evidências"? Por que, apesar de discutirmos um caso de Migrânea Crônica, em nenhum momento pensamos - e me incluo neste rol - em usar Toxina Botulínica? Será que a Medicina Baseada em Evidência não é plenamente aplicável à vida real e os protocolos são guias particularmente úteis aos não especialistas? Seria o "toque do chef" dos ultra especialistas uma consequência natural da árdua dedicação aos estudos, além do conjunto de experiência adquirida dos milhares de pacientes atendidos ao longo dos anos, ao melhor estilo Saint Exupery?

Diante das divagações anteriores, lembro da excelente palesta do Dr Luiz Paulo Queiroz, que nos brindou com assertivas referentes às peculiaridades do manejo dos cefaleicos usuários do SUS.

Claramente saímos de sua aula com o reforço da ideia de que nós, médicos neurologistas e especialistas em cefaleias, somos a solução - ou parte dela-dentro de um contexto de dificuldades, especialmente de falta de medicamentos ou mesmo da indisponibilidade das meIhores opções terapêuticas em alguns casos.

Nesse átimo percebo então que talvez essas duas discussões do XXX Congresso Brasileiro de Cefaleia tenham uma ligação direta entre elas: "...vende mais porque é fresquinho ou é fresquinho porque vende mais"?

Certamente todos nós, médicos brasileiros, em maior ou menor escala já vivenciamos a realidade do SUS e, de certa forma, as dificuldades estruturais deste sistema nos levaram a encontrar alternativas para a investigação diagnóstica e o tratamento de muitos dos pacientes que avaliamos. Porém, o fato de conseguirmos efetivamente lidar com adversidades não deveria ser um limitante ou justificativa tácita para não lutarmos pela inclusão em protocolos de dispensação de medicamentos que julguemos pertinentes ao tratamentos de nossos clientes. Acrescento aos motivos de diversidade de condutas as particularidades de cada região em que atende cada especialista, infelizmente encarada de forma natural num país de dimensões continentais e com população cada vez mais dependente das decisões políticas que interferem na saúde pública.

Realmente o tema é complexo e somos apenas uma parte do todo. Porém, somos a parte que tem respaldo na experiência prática do contato direto com o portador do problema, e respaldo na literatura médico científica. Façamos então a nossa "Escolha de Sofia": se acreditamos na nossa capacidade de improvisar, de realizar combinações magistrais de fármacos e medidas não medicamentosas disponíveis ou, se compraremos a difícil peleja de tentar convencer os órgãos competentes para que disponibilizem e incorporem as inovações farmacológicas e tecnológicas da nossa especialidade. Seria gratificante, além de utópico, pensar em um mundo ideal, em que faríamos uma escolha terapêutica específica por acreditarmos em sua superioridade e não por esta ser apenas a única opção disponível.

Alan Chester Feitosa de Jesus Membro Efetivo da Sociedade Brasileira de Cefaleia

Recebido: $1^{\circ}$ de novembro de 2016

Aceito: 3 de novembro de 2016 